9-2008

\title{
Crowding in Context: An Examination of the Differential Responses of Men and Women to High-Density Living Environments
}

\author{
Wendy C. Regoeczi \\ Cleveland State University, w.regoeczi@csuohio.edu
}

Follow this and additional works at: https://engagedscholarship.csuohio.edu/clsoc_crim_facpub

Part of the Medicine and Health Commons, and the Social Psychology and Interaction Commons How does access to this work benefit you? Let us know!

\section{Publisher's Statement}

(c) 2008 Sage Publications, Inc.

\section{Repository Citation}

Regoeczi, Wendy C., "Crowding in Context: An Examination of the Differential Responses of Men and Women to High-Density Living Environments" (2008). Sociology \& Criminology Faculty Publications. 125. https://engagedscholarship.csuohio.edu/clsoc_crim_facpub/125

This Article is brought to you for free and open access by the Sociology \& Criminology Department at EngagedScholarship@CSU. It has been accepted for inclusion in Sociology \& Criminology Faculty Publications by an authorized administrator of EngagedScholarship@CSU. For more information, please contact library.es@csuohio.edu. 


\title{
Crowding in Context: An Examination of the Differential Responses of Men and Women to High-Density Living Environments*
}

\author{
WENDY C. REGOECZI \\ Cleveland State University
}

\begin{abstract}
This study examines the question of gender-equivalent outcomes of mental health and social behavior in the context of crowding stress. It tests the hypothesis that gender will influence the exhibition of stress outcomes resulting from exposure to high-density living environments, with women displaying internalized responses and men responding with externalized styles. Expanding on the types of gender-appropriate disorders examined in this area of research, I selected depression, aggression, and withdrawal as gender-specific disorders based on theory and prior research. Multilevel analyses of data from a survey of Toronto residents indicate that, while the effects of household density are conditioned by gender, support for the existence of gender-equivalent outcomes is mixed. While women living in crowded homes are more likely to be depressed, men exposed to high-density living environments do not report increased aggression. However, men report higher levels of withdrawal, and some males respond with both aggression and withdrawal.
\end{abstract}

A growing body of literature examines the relationship between environmental stressors and mental health outcomes. However, this research has been criticized for its reliance on measures of internalized symptoms such as depression and anxiety (Horwitz and Davies 1994; Horwitz, White, and Howell-White 1996). Examining single outcomes misses the possibility that responses to exposure to stress may vary across individuals, and this strategy results in an underestimation of the overall influence of the stressor (Cassel 1974; Pearlin 1989). The reliance on single outcome measures, particularly internalized outcomes, may

\footnotetext{
* I am grateful to A. R. Gillis, Blair Wheaton, Robert Silverman, Vincent Sacco, William Magee, Terry Miethe, the anonymous reviewers, and Editors Michael Hughes and Peggy Thoits for their extremely valuable comments. Address correspondence to Wendy C. Regoeczi, Department of Sociology, Cleveland State University, 2121 Euclid Avenue, Cleveland, OH 44115-2214 (e-mail: w.regoeczi@csuohio.edu).
}

be especially problematic when estimating gender differences in response to stressors as higher rates of internalized distress among women are well documented (see, for review, Cleary 1987; Dohrenwend and Dohrenwend 1976; Dohrenwend et al. 1980; Gove 1979; Nolen-Hoeksema 1987); and males exhibit higher rates of antisocial personality and alcohol and drug use and abuse (Aneshensel et al. 1991; Horwitz and Davies 1994; Horwitz and White 1987; Kessler et al. 1994; Lennon 1987; Myers et al. 1984; Regier et al. 1988; Robins et al. 1984; Rosenfield 1999; Simon 1998).

This paper argues that our understanding of the social and behavioral consequences of crowding across different social groups has been obscured by relying on single outcome measures because these groups likely exhibit different responses to stressors (Aneshensel, Rutter, and Lachenbruch 1991; Horwitz 2002; Horwitz et al. 1996). More specifically, reliance on gender-linked outcome measures in prior research may have led some researchers 
to conclude that women are more negatively affected by high density living ${ }^{1}$ than men. The current study extends previous research supporting the notion of gender-equivalent responses to the same stressor (Horwitz and Davies 1994; Horwitz and White 1991; Horwitz et al. 1996) by exploring the existence of gender-equivalent outcomes for the environmental stressor of high-density living environments.

\section{THEORY AND EVIDENCE}

\section{Responses to Crowding Stressors}

In this article, I argue that there is a need to rethink the way that effects of density on human social behavior have been specified, particularly the failure to examine the possibility that men and women may be differentially affected by density. There are several theoretical reasons to expect that men and women will exhibit different responses to crowding stress. Gender stratification and divisions of power likely impact how males and females respond to high-density living environments. Power shapes people's perceptions of their ability to act on and influence the environment (Rosenfield 1992). Furthermore, adult social roles shape the lives of men and women differently (Turner and Turner 1999). Even today, women remain primarily responsible for domestic labor and emotion work (Rosenfield, Vertefuille, and McAlpine 2000). These divisions in power and labor lead to women placing a greater emphasis on the collectivity. However, attending to the feelings and desires of others interferes with one's ability to act in one's own interest and results in a lower sense of control (Rosenfield 1999). In the case of crowding, these divisions will make it difficult, if not impossible, for women to withdraw from the crowded living situation or aggressively reassert control over their own environment. Unable to meet their own needs or establish a sense of control, women may feel helpless and hopeless, resulting in symptoms of depression (Rosenfield et al. 2000). In contrast, the tendency of males to emphasize their own interests over others encourages the view that these others are an interference to be moved out of the way (Rosenfield 2000). The social roles and power of men thus provide a context for males to use aggression to cope with crowding stress.

Thus, research is needed which simultaneously examines male and female styles of pathology in order to investigate whether men and women respond differently to crowded living environments. I explore four outcome measures in this study: depression, aggression, withdrawal, and the combination of aggression and withdrawal.

Depression. Because internalized responses to stressors in the form of depression and anxiety are more consistent with sex-role socialization and cultural norms regarding appropriate gender roles for women (Cloward and Piven 1990; Rosenfield 1980), I select depression as the female-typed reaction to crowding stress.

Aggression. Externalized feelings of distress in the form of alcohol use and abuse and other means of acting out are culturally normative forms of male behavior (Robbins 1989). Studies find lower thresholds of frustration among males, leading to more impulsive and aggressive behavior (see Gove 1979). In arguing for the need to expand outcome measures to include violent behavior, Umberson, Williams, and Anderson (2002) remark that alcohol abuse has come to be the classic measure of externalized distress in sociological research. However, externalizing styles consist of various forms of behavioral expression, including suicide, alcohol consumption, and antisocial behavior. Just as violent behavior can be regarded as an externalized expression of psychological distress, so can aggressive behavior.

Several studies report a positive relationship between density and various forms of aggression and violence (e.g., Booth, Welch, and Johnson 1976; Booth and Edwards 1976; Gove and Hughes 1983; Gove, Hughes, and Galle 1979). Freedom of choice and access to resources may be limited in crowded environments (Altman 1975; Baldassare 1979; Baron and Rodin 1978; Baum and Valins 1979). Aggression may be an effective reaction in such situations, encouraging others to relocate elsewhere, relinquishing some of their space to the aggressive individual, in turn alleviating a number of the constraints connected with crowding (Baum and Paulus 1991).

Withdrawal. High-density environments may lead to withdrawal from social life (Altman 1975; Milgram 1970; Wirth 1938). Consistent exposure to other individuals is stressful. People in urban areas are exposed to more social information than can be suitably processed. The result is a kind of nervous sys- 
tem overload, which Simmel ([1905] 1957) termed "overstimulation," producing aloof attitudes toward others. A number of studies reveal clear manifestations of social withdrawal as a response to crowding among adults and children (e.g., Aiello, Thompson, and Baum 1984; Baum and Paulus 1991; Gove and Hughes 1983; Loo 1972, 1973; Sundstrom 1978).

A fourth outcome: aggression and withdrawal. This article examines whether males not only report more aggression and withdrawal due to exposure to high-density situations, but also whether a single individual uses both types of behavioral responses. In other words, individuals who are highly aggressive are not necessarily withdrawn. This pattern is evident in the findings of Umberson and colleagues (2002) who find a significantly greater likelihood of engaging in domestic violence among men who also exhibit tendencies to avoid/withdraw from partner conflict. This article hypothesizes that the co-existence of aggression and withdrawal will be most likely to occur among males.

\section{Prior Research on Gender and Crowding}

Although the view that crowded living environments are unhealthy is well supported by research on animal populations, findings from studies on the effects of crowding among humans have been far less consistent. For example, analyses by Booth and his colleagues of data derived from a sample of Toronto families failed to reveal support for effects of neighborhood and household crowding on mental health (Booth and Cowell 1976), and of crowding on family relations (Booth and Edwards 1976), but they did reveal some effect of perceived space and privacy on the mental and physical health of women (Duvall and Booth 1978). In contrast, Gove and his colleagues $(1979,1983)$ argue that their research demonstrates substantial health effects resulting from household crowding.

That males and females may react differently to crowded situations may be central to understanding the inconsistent findings of past research. Of the studies to date (summarized in the appendix), some use samples consisting of males only (e.g., Dooley 1978; Evans et al. 1989; Marsella, Escudero, and Gordon 1970; Rodin, Solomon, and Metcalf 1978) or females only (e.g., Duvall and Booth 1978; Gabe and Williams 1986; Ineichen and Hooper 1974; Mackintosh, West, and Saegert 1975), preclud- ing an examination of gender-specific responses to density.

The findings of several studies support the notion that men and women may be differentially affected by high-density situations. For example, Gillis (1977) found a positive relationship between the floor level of the dwelling unit and psychological strain for women and a negative relationship between these variables for men. Other research shows that males are more negatively affected by household crowding than women (Booth and Cowell 1976). Gove and Hughes (1983), in contrast, find a tendency for women, especially married women, to be more affected than men.

Experimental research varying room size reveals a relatively consistent pattern of gender differences, with more aggressive responses to limited space found among males than those observed among women (Baum and Koman 1976; Epstein and Karlin 1975; Freedman et al. 1972; Mackintosh, Saegert, and West 1975; Stokols et al. 1973). Studies examining the effects of density on children also report sex differences in responses to density, with boys displaying heightened aggression (Loo 1972, 1978). Research on gender differences in withdrawal has produced more mixed findings (e.g., Loo 1978). Still other research finds no evidence of sex differences in discomfort as a result of crowding (Aiello, Epstein, and Karlin 1975; Baum and Valins 1977) or in the impact of crowding (Evans et al. 2000). Several longitudinal studies of the impact of household crowding on psychological distress among college students reveal no differential effect by gender (Evans and Lepore 1993; Lepore, Evans, and Schneider 1991). However, Karlin, Epstein, and Aiello (1978) report more physical and psychological problems among crowded women than men.

However, the bulk of previous research, especially non-experimental studies, fails to look at whether men and women have different reactions to density, which may have obscured the findings. Given that women are more prone to internalized outcomes such as depression and men are more inclined to externalized outcomes such as violence, it is imperative to investigate whether males react aggressively and females become depressed when exposed to high-density environments. 


\section{METHODOLOGY}

\section{Sample}

The current research uses data from the Toronto Mental Health and Stress Study to assess differential outcomes of men and women to high-density living environments. The design of the study involved a multi-stage cluster sampling strategy. Investigators randomly selected individuals from households in a representative sample of dwelling addresses drawn from within 200 "census enumeration areas" (of a total of 3,088 census enumeration areas that comprise the six borough target areas). The first wave, conducted in 1990-1991, yielded 1,393 interviews (with a response rate of $75.3 \%$ ). The second wave, conducted approximately one year later, reinterviewed 1,206 respondents (with a response rate of $86.6 \%$ ).

The location of the study is especially valuable in light of the subject matter. A common criticism of early correlational studies of the relationship between density and various forms of social pathology was their inability to distinguish between the effects of density per se and the effects of factors like poverty, which tend to coexist with high density (see Factor and Waldron 1973; Gove and Hughes 1983). However, Toronto is unusually structured in the sense that high-rise buildings are spread across neighborhoods of varying socioeconomic levels. Therefore, the presence of a crowding-SES correlation is offset by the fact that some of the more crowded areas of the city are high socioeconomic neighborhoods. Further, more suburban areas, which are lower in density, are often not high in socioeconomic status.

The possibility of a self-selection of individuals into certain residential environments is a major issue in crowding research. Persons who have physical or mental difficulties or have tendencies toward antisocial behavior may be drawn to dense urban areas, or they may be compelled to live there by economic or social constraints (Baum and Paulus 1991). The longitudinal component of the Toronto Mental Health and Stress Study permits an examination of the effects of density on depression, aggression, and withdrawal while controlling for prior levels of these variables, making it possible to control for self-selection.

\section{Independent Variables}

Household density. The survey contains data on the number of persons in the household and the number of rooms in the household, and thus persons per room can be calculated by dividing the latter by the former. I tested squared and cubed versions and included them in the models when significant, as both low and high levels of crowding may negatively impact mental health. Further, previous analyses of these data revealed non-linear effects of household density, a pattern supported elsewhere (e.g., Gabe and Williams 1986; Galle and Gove 1978; Gillis 1979; Regoeczi 2002). The use of persons per room as a measure of crowding has been validated by Gove et al. (1979, 1983), who demonstrate that persons per room is strongly related to both lack of privacy and felt demands.

Neighborhood density. I measured neighborhood density by dividing the total population of the neighborhood by the number of residences in the "forward sortation area" (FSA) of the postal code. ${ }^{2}$ While a given FSA may not correspond precisely with neighborhood boundaries, it does provide an indication of the areal characteristics in which a household is located.

Sex. I measure respondent's sex with a binary variable for which females were assigned a value of 1 and males were assigned a value of 0 .

\section{Dependent Variables}

Depression. I measured depression using the Center for Epidemiologic Studies Depression Scale (CES-D). This scale is frequently used to measure depression and has been shown to have high reliability (Radloff 1977). For the current study, Cronbach's alpha was .91 for both waves.

Aggression. I constructed a scale of aggressive behavior on the basis of the responses to the following self-ratings: "I am too aggressive toward other people" $(0=$ "not at all well" to 4 = "extremely well"); "I manipulate other people too much to get what I want" $(0=$ "not at all well" to 4 = "extremely well"); "submissive/forceful" ( 1 = "submissive" to 7 = "forceful"); "not at all aggressive/aggressive" (1 = "not at all aggressive" to 7 = "aggressive"); "I like people to be afraid of me"; "I try to get into positions of authority" ( 1 = "very unlike me" to $5=$ "very like me") (scale alpha $=.69$ for wave 1 and .70 for wave 2). Higher values on these statements should reflect greater levels of self-salience, personal control, and a tendency to put one's own interests first while viewing 
others as an interference, all of which are conducive to externalized responses to stress (Rosenfield 2000; Rosenfield et al. 2000).

Withdrawal. I constructed a scale measuring withdrawn behavior on the basis of respondent self-ratings on the following statements: "I keep other people at a distance too much"; "It is hard for me to feel close to other people"; "It is hard for me to experience a feeling of love for another person"; "It is hard for me to show affection to other people"; "It is hard for me to socialize with other people"; "It is hard for me to introduce myself to new people"; "It is hard for me to join in on groups." The items were scaled such that $0=$ "not at all well"; $2=$ "moderately well"; 4 = "extremely well" (scale alpha $=.87$ for both waves).

Combined categorical variable. Aggression and withdrawal in their continuous forms were combined into a four-category nominal-level variable by dividing them at their mean values and then combining them to create four categories: low aggression/low withdrawal $(n=$ 404 at time $1 ; n=452$ at time 2 ), low aggression/high withdrawal $(n=298$ at time $1 ; n=$ 240 at time 2), high aggression/low withdrawal $(n=352$ at time $1 ; n=312$ at time 2$)$, and high aggression/high withdrawal $(n=313$ at time $1 ; n=363$ at time 2 ).

\section{Control variables}

Each model includes a series of control variables that have been established as predictors of depression, withdrawal, and violent behav- ior. I present descriptive statistics for these and all other variables in Table 1. With the exception of gender, all control variables are grandmean centered.

\section{Analysis}

The nested structure of the data set (individuals nested in neighborhoods) required the use of a program that could incorporate its multilevel nature. In order to account for the complex error structure of the data, I carried out the analyses using hierarchical linear modeling or HLM (Raudenbush, Bryk, and Congdon 2000). Ordinary least squares regression assumes homoscedasticity and independent residuals, both of which are violated when using nested data. Under such circumstances, estimation by iterative maximum likelihood is appropriate. The final models included significant random effects for the intercept and some of the slopes, further emphasizing the need to use a technique like hierarchical linear modeling to appropriately model these data.

\section{RESULTS}

Table 2 reports the results of the analyses examining the effects of gender, household density, neighborhood density, and the control variables on depression, aggression, and withdrawal. In all six models, prior levels of reported depression, aggression, or withdrawal are strong predictors of current levels of these outcomes, underscoring the importance of controlling for self-selection. Model 1 shows a sig-

\section{TABLE 1. Descriptive Statistics}

\begin{tabular}{lrr}
\hline \hline & Mean & $\begin{array}{c}\text { Standard } \\
\text { Deviation }\end{array}$ \\
\hline Persons per room (wave 1) & .535 & .311 \\
Persons per room (wave 2) & .560 & .384 \\
Depression (wave 1) & 11.877 & 9.387 \\
Depression (wave 2) & 10.455 & 8.838 \\
Aggression (wave 1) & 14.775 & 4.302 \\
Aggression (wave 2) & 14.719 & 4.207 \\
Withdrawal (wave 1) & 6.872 & 5.970 \\
Withdrawal (wave 2) & 6.713 & 5.705 \\
Persons per residence & 17.697 & 11.248 \\
Female & .566 & .496 \\
Household income (15-point scale ranging from & 8.863 & 3.080 \\
$\quad$ under 5,000 to 135,000 and above) & \\
Currently married & .483 & .450 \\
Never married & .391 & .488 \\
Previously married & .126 & .332 \\
Black & .080 & .271 \\
East Asian & .083 & .275 \\
South Asian & .046 & .210 \\
Euro-Mediterranean & .228 & .419 \\
Age (in years) & 36.66 & 10.01 \\
\hline
\end{tabular}


TABLE 2. Hierarchical Linear Models Testing for Conditional Effects of Gender on Persons per Room for Depression, Withdrawal and Aggression $(N=1,018)$

\begin{tabular}{|c|c|c|c|c|c|c|}
\hline & $\begin{array}{c}\text { Model } 1 \\
\text { Coefficient } \\
\text { (Std. error) }\end{array}$ & $\begin{array}{l}\text { Model } 2 \\
\text { Coefficient } \\
\text { (Std. error) }\end{array}$ & $\begin{array}{c}\text { Model } 3 \\
\text { Coefficient } \\
\text { (Std. error) }\end{array}$ & $\begin{array}{c}\text { Model } 4 \\
\text { Coefficient } \\
\text { (Std. error) }\end{array}$ & $\begin{array}{l}\text { Model } 5 \\
\text { Coefficient } \\
\text { (Std. error) }\end{array}$ & $\begin{array}{l}\text { Model } 6 \\
\text { Coefficient } \\
\text { (Std. error) }\end{array}$ \\
\hline & \multicolumn{2}{|c|}{ Depression } & \multicolumn{2}{|c|}{ Withdrawal } & \multicolumn{2}{|c|}{ Aggression } \\
\hline Intercept & $\begin{array}{l}12.553 * * * \\
(.789)\end{array}$ & $\begin{array}{l}12.616^{* * * *} \\
(.796)\end{array}$ & $\begin{array}{l}7.359 * * * \\
(.227)\end{array}$ & $\begin{array}{l}7.215^{* * *} \\
(.228)\end{array}$ & $\begin{array}{c}14.977 * * * \\
(.143)\end{array}$ & $\begin{array}{c}14.947 * * * \\
(.171)\end{array}$ \\
\hline Persons per room & $\begin{array}{c}1.941 \\
(1.128)\end{array}$ & $\begin{array}{l}2.425 \\
(1.590)\end{array}$ & $\begin{array}{l}-.036 \\
(.753)\end{array}$ & $\begin{array}{l}-1.113 \\
(1.150)\end{array}$ & $\begin{array}{l}-.023 \\
(.426)\end{array}$ & $\begin{array}{l}-.587 \\
(.658)\end{array}$ \\
\hline$(\text { Persons per room })^{2}$ & $\begin{array}{c}-2.342^{*} \\
(1.136)\end{array}$ & $\begin{array}{l}-3.526^{* *} \\
(1.312)\end{array}$ & $\begin{array}{l}.096 \\
(.463)\end{array}$ & $\begin{array}{l}2.123 * \\
(1.076)\end{array}$ & $\begin{array}{l}-.024 \\
(.148)\end{array}$ & $\begin{array}{l}.599 \\
(.766)\end{array}$ \\
\hline$(\text { Persons per room })^{3}$ & $\begin{array}{l}.478^{*} \\
(.243)\end{array}$ & $\begin{array}{l}.608^{*} \\
(.260)\end{array}$ & $\mathrm{n} / \mathrm{a}$ & $\mathrm{n} / \mathrm{a}$ & $\mathrm{n} / \mathrm{a}$ & $\mathrm{n} / \mathrm{a}$ \\
\hline Persons per residence & $\begin{array}{l}-.018 \\
(.024)\end{array}$ & $\begin{array}{l}-.019 \\
(.024)\end{array}$ & $\begin{array}{l}-.030 * * \\
(.010)\end{array}$ & $\begin{array}{l}-.030^{* *} \\
(.010)\end{array}$ & $\begin{array}{l}.001 \\
(.007)\end{array}$ & $\begin{array}{l}.002 \\
(.007)\end{array}$ \\
\hline Depression (time 1) & $\begin{array}{l}.495^{* * *} \\
(.029)\end{array}$ & $\begin{array}{l}.496 * * * \\
(.030)\end{array}$ & $\mathrm{n} / \mathrm{a}$ & $\mathrm{n} / \mathrm{a}$ & $\mathrm{n} / \mathrm{a}$ & $\mathrm{n} / \mathrm{a}$ \\
\hline Withdrawal (time 1) & $\mathrm{n} / \mathrm{a}$ & $\mathrm{n} / \mathrm{a}$ & $\begin{array}{l}.661^{* * * *} \\
(0.026)\end{array}$ & $\begin{array}{l}.660 * * * \\
(0.027)\end{array}$ & $\mathrm{n} / \mathrm{a}$ & $\mathrm{n} / \mathrm{a}$ \\
\hline Aggression (time 1) & $\mathrm{n} / \mathrm{a}$ & $\mathrm{n} / \mathrm{a}$ & $\mathrm{n} / \mathrm{a}$ & $\mathrm{n} / \mathrm{a}$ & $\begin{array}{l}.705^{* * *} \\
(.021)\end{array}$ & $\begin{array}{l}.709 * * * \\
(.021)\end{array}$ \\
\hline Female & $\begin{array}{l}1.011^{*} \\
(.430)\end{array}$ & $\begin{array}{l}.891^{*} \\
(.430)\end{array}$ & $\begin{array}{c}-1.115 * * * \\
(.279)\end{array}$ & $\begin{array}{l}-.946^{* * * *} \\
(.281)\end{array}$ & $\begin{array}{l}-.425^{*} \\
(.173)\end{array}$ & $\begin{array}{l}-.434 * \\
(.196)\end{array}$ \\
\hline $\begin{array}{l}(\text { Female }) \times(\text { Persons } \\
\text { per room })\end{array}$ & & $\begin{array}{l}-.520 \\
(1.832)\end{array}$ & & $\begin{array}{l}1.345 \\
(1.197)\end{array}$ & & $\begin{array}{l}.627 \\
(.853)\end{array}$ \\
\hline $\begin{array}{l}(\text { Female }) \times(\text { Persons } \\
\text { per room })^{2}\end{array}$ & & $\begin{array}{l}1.148^{*} \\
(.580)\end{array}$ & & $\begin{array}{l}-2.420^{*} \\
(1.175)\end{array}$ & & $\begin{array}{l}-.342 \\
(.875)\end{array}$ \\
\hline Household income & $\begin{array}{l}.329 * * * \\
(.075)\end{array}$ & $\begin{array}{l}-.324 * * * \\
(.075)\end{array}$ & $\begin{array}{l}.067 \\
(.045)\end{array}$ & $\begin{array}{l}.059 \\
(.045)\end{array}$ & $\begin{array}{l}.080^{*} \\
(.033)\end{array}$ & $\begin{array}{l}.082^{*} \\
(.033)\end{array}$ \\
\hline Age & $\begin{array}{l}.027 \\
(.028)\end{array}$ & $\begin{array}{l}.027 \\
(.028)\end{array}$ & $\begin{array}{l}.021 \\
(.017)\end{array}$ & $\begin{array}{l}.019 \\
(.017)\end{array}$ & $\begin{array}{l}-.002 \\
(.012)\end{array}$ & $\begin{array}{l}-.003 \\
(.011)\end{array}$ \\
\hline Never married ${ }^{a}$ & $\begin{array}{l}.651 \\
(.617)\end{array}$ & $\begin{array}{l}.685 \\
(.613)\end{array}$ & $\begin{array}{c}.425 \\
(.399)\end{array}$ & $\begin{array}{l}.371 \\
(.396)\end{array}$ & $\begin{array}{l}-.068 \\
(.309)\end{array}$ & $\begin{array}{l}-.102 \\
(.294)\end{array}$ \\
\hline Previously married ${ }^{\mathrm{a}}$ & $\begin{array}{l}.295 \\
(.851)\end{array}$ & $\begin{array}{l}.287 \\
(.850)\end{array}$ & $\begin{array}{l}.409 \\
(.450)\end{array}$ & $\begin{array}{l}.316 \\
(.445)\end{array}$ & $\begin{array}{l}.118 \\
(.304)\end{array}$ & $\begin{array}{l}.091 \\
(.299)\end{array}$ \\
\hline Black $^{\mathrm{b}}$ & $\begin{array}{c}.670 \\
(1.015)\end{array}$ & $\begin{array}{c}.619 \\
(1.028)\end{array}$ & $\begin{array}{l}-.050 \\
(.658)\end{array}$ & $\begin{array}{l}.105 \\
(.652)\end{array}$ & $\begin{array}{c}.032 \\
(.316)\end{array}$ & $\begin{array}{l}.045 \\
(.317)\end{array}$ \\
\hline East Asian ${ }^{\mathrm{b}}$ & $\begin{array}{l}-.950 \\
(.621)\end{array}$ & $\begin{array}{c}-.977 \\
(.610)\end{array}$ & $\begin{array}{l}-.305 \\
(.456)\end{array}$ & $\begin{array}{l}-.332 \\
(.456)\end{array}$ & $\begin{array}{l}.221 \\
(.410)\end{array}$ & $\begin{array}{l}.235 \\
(.415)\end{array}$ \\
\hline South Asian ${ }^{\mathrm{b}}$ & $\begin{array}{c}.815 \\
(1.042)\end{array}$ & $\begin{array}{c}.765 \\
(1.032)\end{array}$ & $\begin{array}{l}-.646 \\
(.639)\end{array}$ & $\begin{array}{l}-.596 \\
(.631)\end{array}$ & $\begin{array}{l}-.273 \\
(.652)\end{array}$ & $\begin{array}{l}-.465 \\
(.606)\end{array}$ \\
\hline Euro-Mediterranean $^{\mathrm{b}}$ & $\begin{array}{l}.215 \\
(.668)\end{array}$ & $\begin{array}{l}.183 \\
(.668)\end{array}$ & $\begin{array}{l}-.229 \\
(.402)\end{array}$ & $\begin{array}{l}-.212 \\
(.401)\end{array}$ & $\begin{array}{l}.252 \\
(.237)\end{array}$ & $\begin{array}{l}.278 \\
(.233)\end{array}$ \\
\hline
\end{tabular}

Note: $* p<.05 ; * * p<.01 ; * * * p<.001$ (two-tailed tests)

${ }^{\mathrm{a}}$ Reference category $=$ Currently Married

${ }^{\mathrm{b}}$ Reference category $=$ white

nificant cubic relationship between crowding and depression, with both very low and very high levels of density leading to increased reporting of depression symptoms. The negative sign for the squared term suggests there is a middle range of density that is optimal for mental health. As expected, the coefficient for gender is positive and significant, indicating that women report higher levels of depression than men.

I calculated coefficients for the effects of persons per room on depression for males and females and graphed them together to facilitate drawing comparisons; I present this analysis in Figure 1. Since persons per room is grand- mean centered, I plotted the equations using values of persons per room both above and below the mean of zero. All other variables in the equation were set to their mean values. The graph displays distinctly different relationships for men and women. Men become less depressed once an average level of crowding is reached. For women, depression increases as levels of crowding go from low to average levels, at which point the effect tapers off. However, depression begins to increase again once higher levels of crowding are reached.

Model 3 displays the main effects of crowding and gender on withdrawal. While persons per room does not have a significant effect on 
FIGURE 1. Non-Linear Interaction of Gender and Persons per Room on Depression

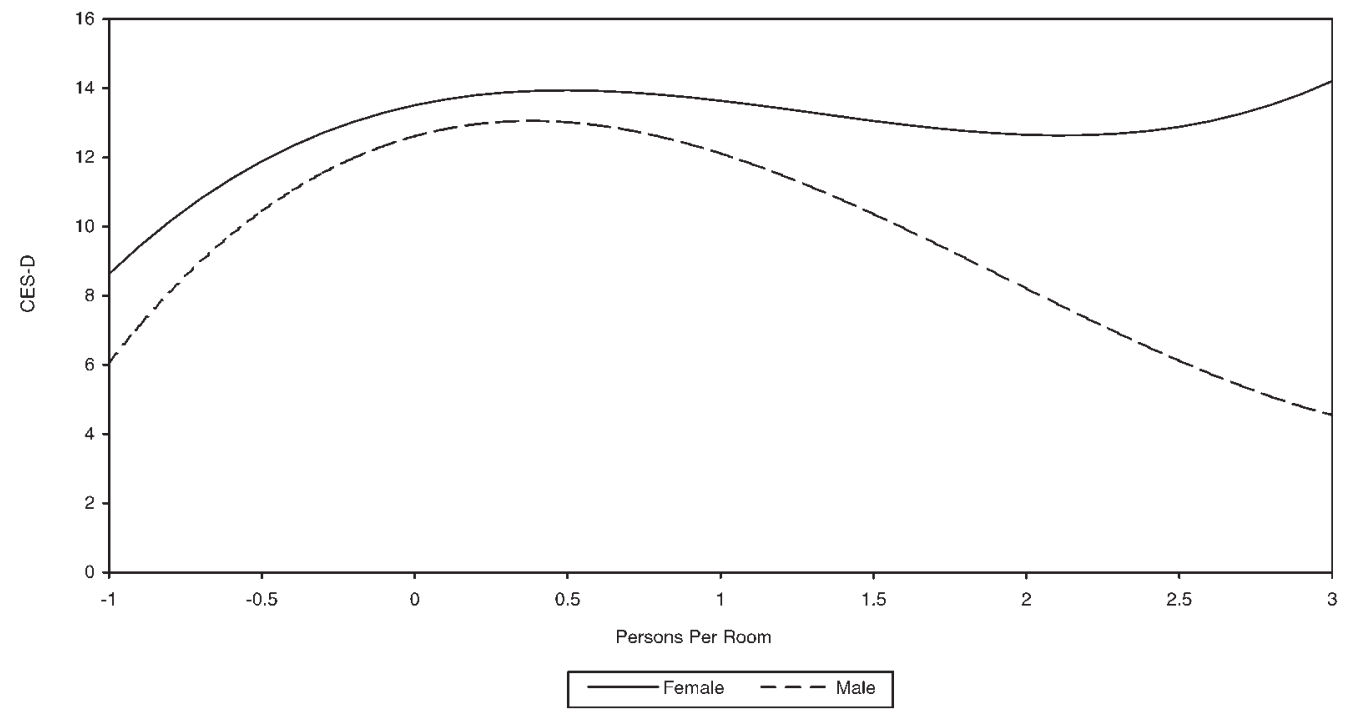

withdrawal in this model, persons per residence in the neighborhood does. The coefficient for gender is also significant and supports the hypothesis that men are more likely to withdraw than women. Model 4 includes two interaction terms in the model testing for conditional effects of gender and crowding on withdrawal. The results reveal significant effects of household and neighborhood density, as well as a significant interaction between gender and persons per room-squared (graphically displayed in Figure 2).

The graph reveals very divergent effects of crowding on the likelihood of withdrawal by men and women. The graph for men shows a Jcurve, with slight declines in withdrawal at low levels of household crowding, but a deleterious positive effect of persons per room beginning to take off once average levels of household crowding are surpassed. The curve for women, on the other hand, is essentially flat.

\section{FIGURE 2. Non-Linear Interaction of Gender and Persons per Room on Withdrawal}

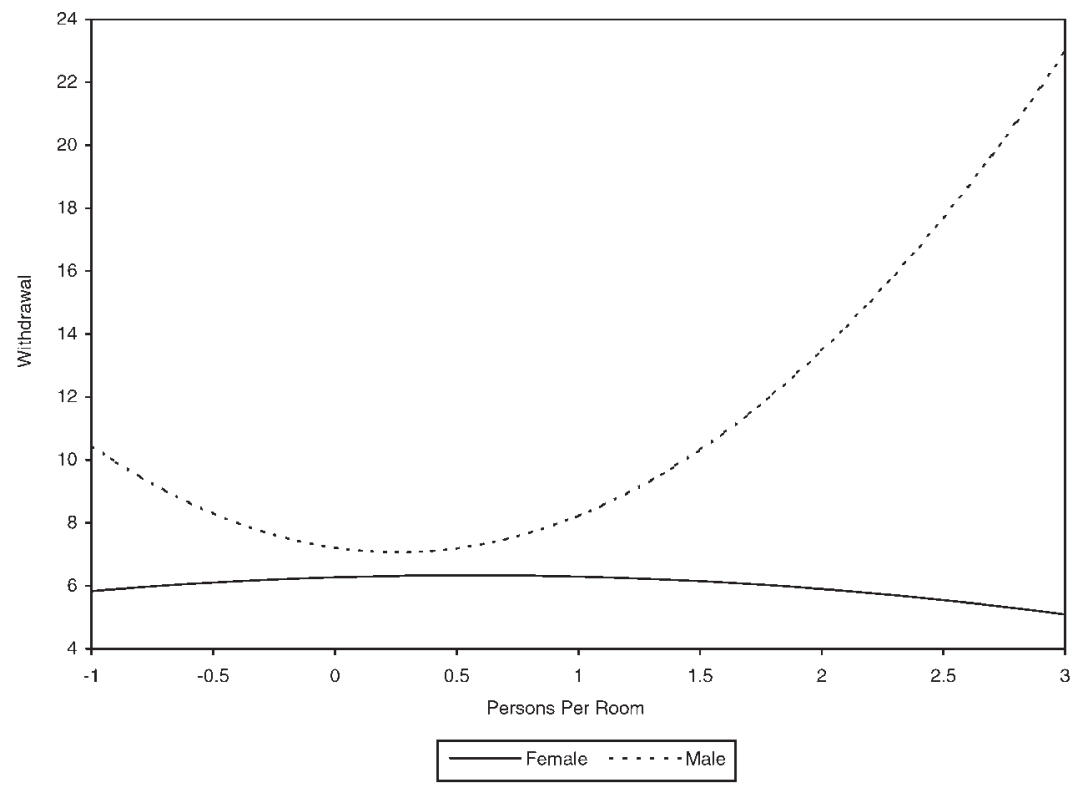


Model 5 reports the results for the main effects of crowding and gender on aggression. While crowding does not have a significant effect on aggression alone, the coefficient for gender is significant, indicating that women are significantly less likely to be aggressive. There are no significant interactions between crowding and gender on aggression (model 6). However, it is still possible that there are gender differences in both aggressive and withdrawn responses together (by the same individual). To test for this possibility, additional models were analyzed using the combined aggression/withdrawal variable. With a four-category dependent variable, the full multinomial model produced three sets of coefficients, each category-low aggression/high withdrawal, high aggression/low withdrawal, and high aggression/high withdrawal - contrasting with the reference category (low aggression/low withdrawal). Since the models in Table 2 have already examined relationships for aggression and withdrawal alone, in the interests of space I report in Table 3 only the coefficients for the comparison between high aggression/high withdrawal versus low aggression/low withdrawal.

In both models displayed in Table 3, prior levels of reported aggression and withdrawal are strong predictors of current levels of these outcomes. Household density has a significant, non-linear effect in model 2 , just missing conventional significance levels in model 1 ( $p=$ $.06)$. Model 1 reveals that gender has a significant main effect for the contrast between high aggression/high withdrawal versus low aggression/low withdrawal; women are significantly less likely to report this combination of responses. Model 2 tests for an interaction between gender and persons per room and squared persons per room, revealing significant interaction terms in both cases. Figure 3 displays this conditional effect graphically.

Figure 3 reveals very divergent patterns for men and women. The effect for men takes the form of a J-curve, with men reporting increasingly high levels of both aggression and withdrawal as a means of coping with crowding stress. It is possible that the use of aggression may allow men to reestablish control over their space within the household. However, since aggressive behavior may be accompanied by an overall deterioration of relationships with others (Booth 1976), withdrawal may also be desirable. Women, on the other hand, are much less likely to report both aggressive and withdrawn behavior, even at very high levels of household density.

TABLE 3. Hierarchical Linear Models Testing for Conditional Effects of Gender on Persons per Room for High Withdrawal/High Aggression $(N=1,018)$

\begin{tabular}{|c|c|c|c|c|}
\hline & \multicolumn{2}{|c|}{$\begin{array}{c}\text { Model 1: } \\
\text { High Aggression/ } \\
\text { High Withdrawal vs. } \\
\text { Low Aggression/Low Withdrawal }\end{array}$} & \multicolumn{2}{|c|}{$\begin{array}{c}\text { Model 2: } \\
\text { High Aggression/ } \\
\text { High Withdrawal vs. } \\
\text { Low Aggression/Low Withdrawal }\end{array}$} \\
\hline & Coefficient & (Std. Error) & Coefficient & (Std. Error) \\
\hline Intercept & $.983 * * *$ & $(.166)$ & $.857 * * *$ & $(.166)$ \\
\hline Persons per room & -.271 & $(.551)$ & -1.454 & $(.827)$ \\
\hline$(\text { Persons per room })^{2}$ & .608 & $(.331)$ & $3.550 * * *$ & $(1.075)$ \\
\hline Persons per residence & -.004 & $(.009)$ & -.002 & $(.009)$ \\
\hline Low aggression/high withdrawal (time 1) & $2.267 * * *$ & $(.353)$ & $2.330 * * *$ & $(.334)$ \\
\hline High aggression/low withdrawal (time 1) & $2.254 * * *$ & $(.339)$ & $2.324 * * *$ & $(.325)$ \\
\hline High aggression/high withdrawal (time 1) & $4.457 * * *$ & $(.465)$ & $4.544 * * *$ & $(.423)$ \\
\hline Female & $-.794 * * *$ & $(.187)$ & $-.624 * * *$ & $(.182)$ \\
\hline$($ Persons per room $) \times($ female $)$ & & & 1.751 & $(1.080)$ \\
\hline$(\text { Persons per room })^{2} \times($ female $)$ & & & $-3.416 * *$ & $(1.114)$ \\
\hline Household income & $.122 * * *$ & $(.037)$ & $.130 * * *$ & $(.036)$ \\
\hline Age & .011 & $(.014)$ & .009 & $(.014)$ \\
\hline Never married ${ }^{a}$ & .248 & $(.324)$ & .231 & $(.317)$ \\
\hline Previously married ${ }^{\mathrm{a}}$ & .228 & $(.361)$ & .277 & $(.358)$ \\
\hline Black $^{\mathrm{b}}$ & -.289 & $(.473)$ & -.220 & $(.456)$ \\
\hline East Asian ${ }^{b}$ & -.647 & $(.341)$ & $-.753 *$ & $(.320)$ \\
\hline South Asian ${ }^{\mathrm{b}}$ & -1.138 & $(.659)$ & -1.133 & $(.616)$ \\
\hline Euro-Mediterranean ${ }^{\mathrm{b}}$ & -.214 & $(.306)$ & -.226 & $(.298)$ \\
\hline
\end{tabular}

Note: $* p<.05 ; * * p<.01 ; * * * p<.001$ (two-tailed test)

${ }^{a}$ Reference category $=$ Currently married

${ }^{\mathrm{b}}$ Reference category $=$ white 
FIGURE 3. Non-Linear Interaction of Gender and Persons Per Room on High Aggression/High Withdrawal vs. Low Aggression/Low Withdrawal

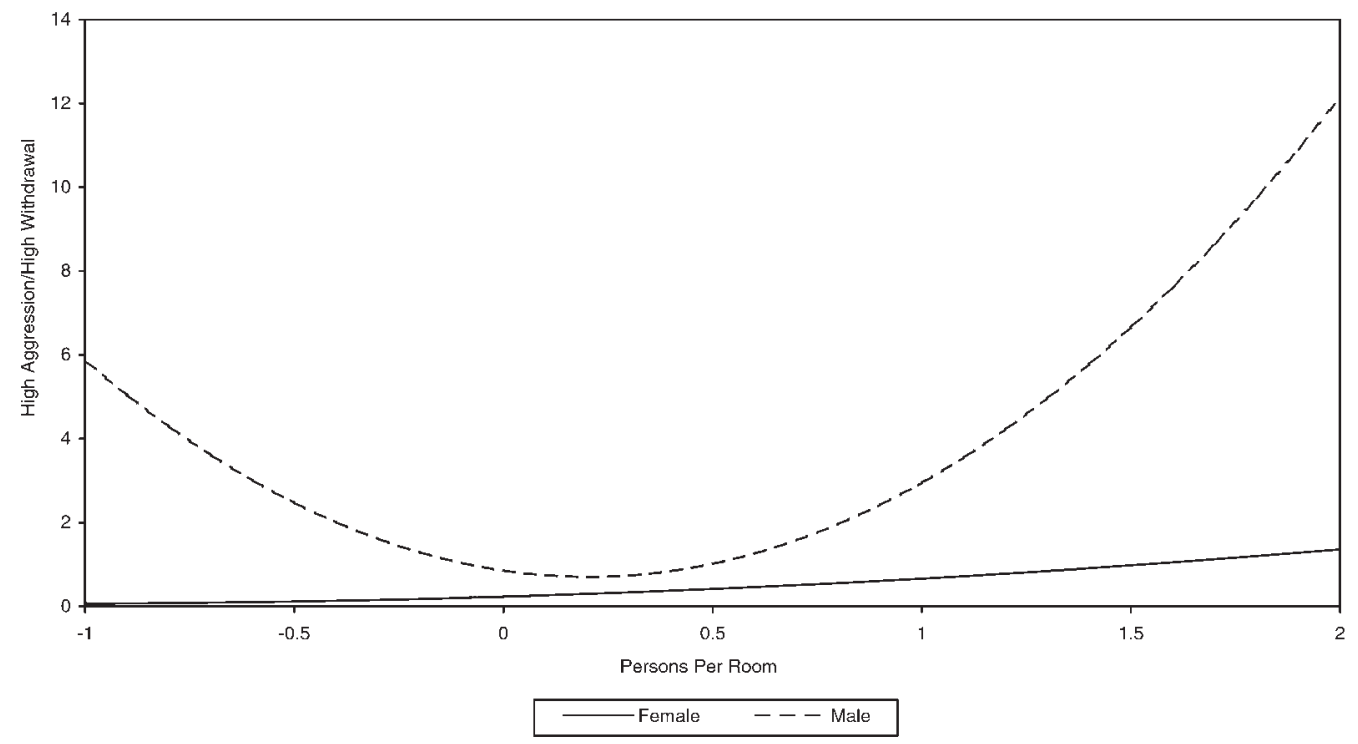

A final set of models tests for interactions between gender and average persons per residence in the neighborhood. No significant interactions emerged between these variables. Thus, differential responses to density across men and women are most evident at the level of household density. This may reflect the fact that this is where most individuals spend the majority of their time (outside of time spent at work) and where the impact of the different roles of men and women are most consequential.

\section{DISCUSSION AND CONCLUSION}

This article seeks to broaden the literature on the existence of gender-equivalent responses to stress in the context of crowding. Mixed support was found for predictions derived from arguments concerning gender-specific outcomes. It was expected that men (but not women) would respond to crowding stress with aggressive behavior, and women (but not men) would respond with increased depression. The latter hypothesis was supported. I examined withdrawal as an additional male-typed response to crowding stress, and the results indicate that men reported higher levels of withdrawal with increasing density. Based on research by Umberson and colleagues (2002), I predicted that the combination of aggression and withdrawal would be most likely to occur among men, and the results support that prediction.

The vulnerability of men to crowding stress may have been understated in prior studies that failed to include both internalized and externalized outcomes. Although greater role obligations experienced by women have been offered as an explanation of their greater reactivity to crowding (see Gove and Hughes 1983), these same responsibilities may limit the available coping mechanisms, increasing the likelihood that their response will manifest as symptoms of depression. The parental and other relationship obligations of women make it difficult to ignore the needs and feelings of others by acting out against them (Rosenfield et al. 2000), reducing the likelihood that they will respond to crowding stress with aggression. Female social roles may also make it difficult to avoid contact with others in spite of the overstimulation caused by high levels of household density. Their roles as mothers, for example, often require interaction with other parents, children, teachers, and additional individuals with whom their children come into contact. Thus, women may have fewer opportunities to resort to withdrawal as a means of coping. Instead, they may seek social support. However, the addition of a variable measuring the presence of children in the household to the interaction models tested in this study produced results (available from the author) vir- 
tually identical to those reported in Table 2, and they did not reduce the interactions between gender and household density to nonsignificance.

The finding that some men respond with the combination of aggression and withdrawal is important as it suggests that withdrawal alone, and combined with aggression, is a genderspecific response. In particular, the current research indicates that both outcomes are exhibited by men. Withdrawal tendencies have not been treated as male-typed responses to stress in previous studies. In much the same way that the roles and responsibilities of women may preclude coping through withdrawal, men may be better able to take advantage of this response. However, they do not withdraw instead of resorting to aggression. Rather, they do both. Thus, when men become frustrated when confronted with the problems of residing in close proximity to many others, they invoke the externalized response of aggression but are also at greater liberty to evade others, spend more time on their own, or withdraw to less dense surroundings either within or outside of the home.

One could argue that men may also be able to use their occupations as a means of withdrawal. This explanation was indirectly tested in supplemental analyses which added a dichotomous measure of employed versus not employed. The results (available from the author) were virtually identical to those presented in Tables 2 and 3. The addition of the employed variable resulted in negligible changes in the coefficients representing interactions between gender and density on withdrawal. The results for the contrast between high aggression/high withdrawal and low aggression/low withdrawal were also essentially unchanged. Thus, these patterns do not appear to be explained by differences in employment status of men and women. The results also diverge from those which have emerged from the experi- mental literature on density. However, they are relatively consistent with animal research in which males (and in some cases females) have been observed to behave aggressively and withdraw under high density conditions (see, for example, Calhoun 1962).

The findings from this study underscore the need to expand the range of measures used to represent gender-specific responses to stress beyond the typical selections of depression and alcohol use and abuse. Gender differences in styles of expressing distress should not be assumed to extend to all varieties of internal and external outcomes. Future efforts should also seek to understand why and how particular individuals exhibit multiple outcomes in response to crowding and other sources of stress.

Future research should consider adopting additional measures of the outcomes used here. Measures of aggression and withdrawal based on observations of behavior as opposed to selfreports would provide an important test of the validity of these findings. Researchers should be encouraged to adopt measures of aggression which are outside the bounds of legal definitions as not all aggression is illegal. The current reliance on measures of violence derived from crime statistics to investigate whether high density produces aggressive behavior raises several concerns regarding the validity of such measures. Crime statistics only tap into the more extreme forms of aggression, as well as being limited to those which are physical in nature, and they therefore miss what is arguably the larger segment of the continuum of aggression-its milder and more subtle forms. That these less extreme forms of aggression (in combination with withdrawal) showed a strong and consistent relationship to high density in the present research suggests that we have only begun to explore the range of gender-specific outcomes that may form responses to crowding stress. 


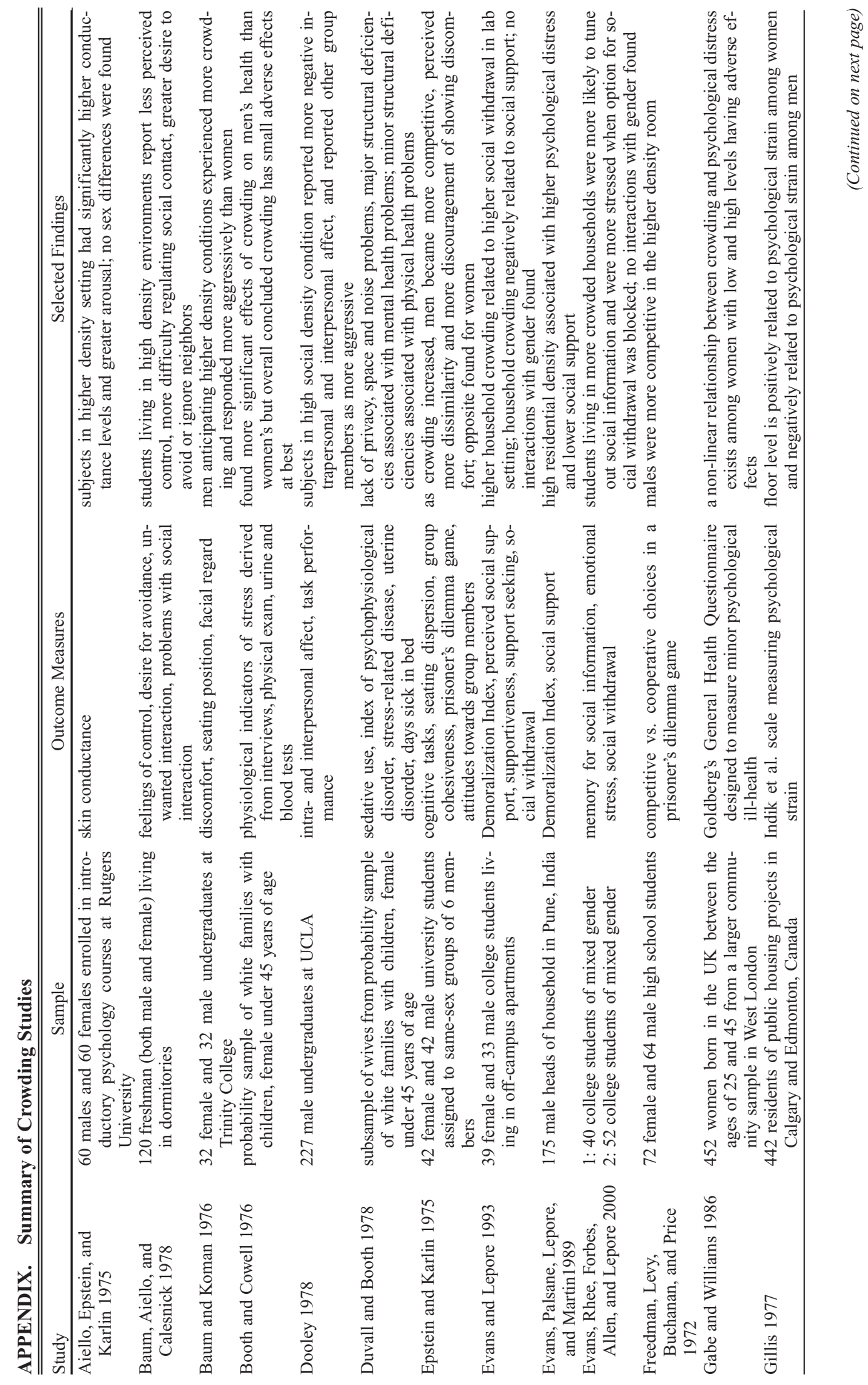




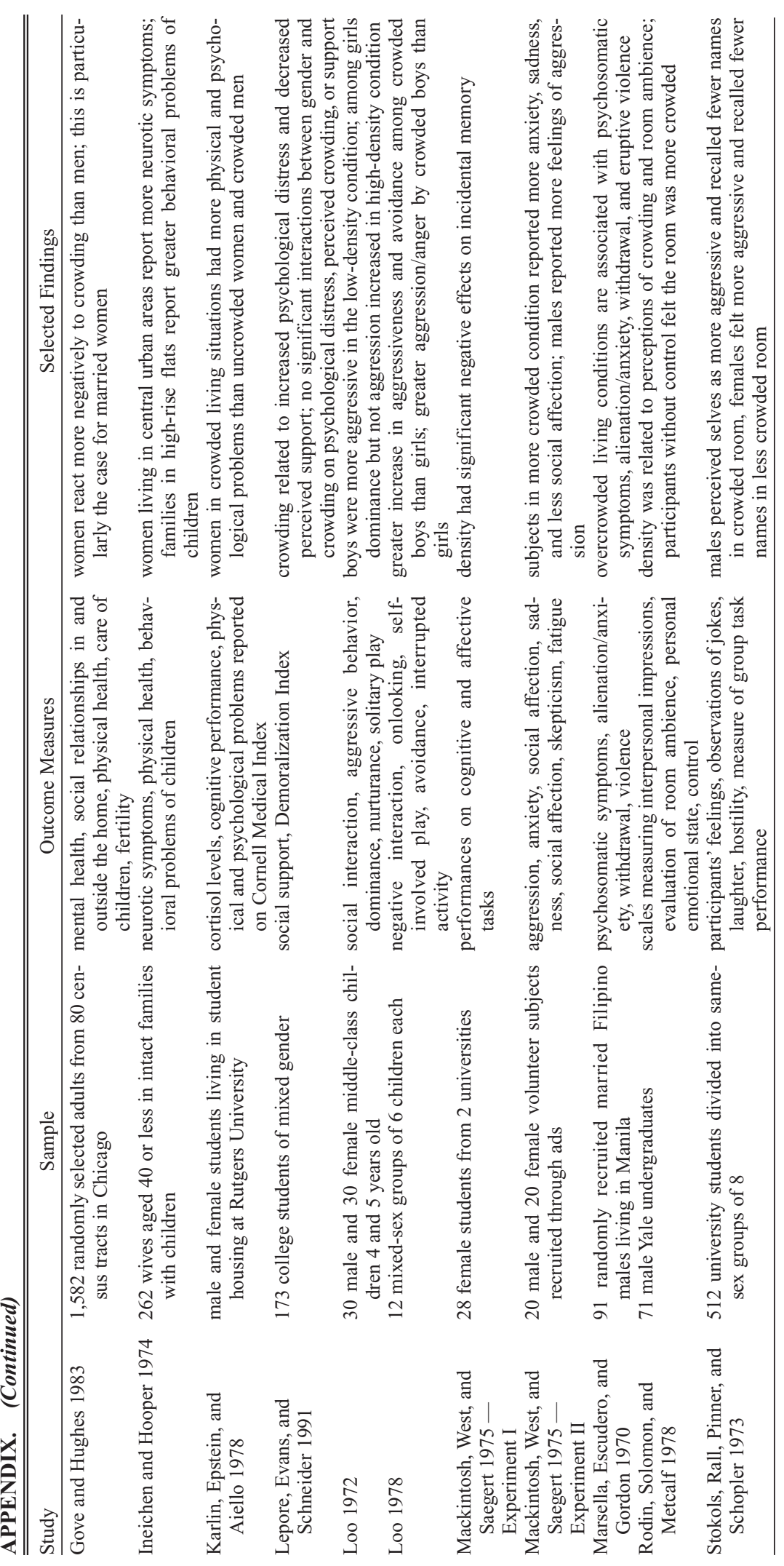




\section{NOTES}

1. Density refers to a physical condition concerning the amount of space available, whereas crowding is the subjective experience which results from perceptions of exposure to limited space (Stokols 1972). Although high density does not unconditionally lead to a perception of crowding, a substantial amount of empirical evidence exists indicating a tendency for high density and crowding to coexist (e.g., Baldassare 1979; Baum, Aiello, and Calesnick 1978; Dooley 1978; Epstein and Karlin 1975; Evans et al. 1989; Mackintosh, West, and Saegert 1975; Rodin et al. 1978; Stokols et al. 1973; Sundstrom 1978). Thus, in this article, I use the two terms interchangeably.

2. "Forward sortation areas" (FSAs) comprise the first three characters of the six-character Canadian postal code. They are generally larger than census tracts, another common proxy for neighborhoods.

\section{REFERENCES}

Aiello, John R., Yakov M. Epstein, and Robert A. Karlin. 1975. "Effects of Crowding on Electrodermal Activity." Sociological Symposium $14: 43-57$.

Aiello, John R., Donna E. Thompson, and Andrew Baum. 1984. "Children, Crowding, and Control: Effects of Environmental Stress on Social Behavior." Pp. 97-124 in Habitats for Children: The Impacts of Density, edited by J. F. Wohlwill and W. van Vliet. Hillsdale, NJ: Erlbaum.

Altman, Irwin. 1975. The Environment and Social Behavior. Monterey, CA: Brooks/Cole.

Aneshensel, Carol S., Carolyn M. Rutter, and Peter A. Lachenbruch. 1991. "Social Structure, Stress, and Mental Health: Competing Conceptual and Analytic Models." American Sociological Review 56:166-78.

Baldassare, Mark. 1979. Residential Crowding in Urban America. Berkeley: University of California Press.

Baron, Reuben M. and Judith Rodin. 1978. "Personal Control and Crowding Stress: Processes Mediating the Impact of Spatial and Social Density." Pp. 145-90 in Advances in Environmental Psychology, vol. 1, edited by A. Baum, J. M. Singer, and S. Valins. Hillsdale, NJ: Erlbaum.

Baum, Andrew, John R. Aiello, and Lisa E. Calesnick. 1978. "Crowding and Personal Control: Social Density and the Development of Learned Helplessness." Journal of Personality and Social Psychology 36:1000-11.

Baum, Andrew and Stuart Koman. 1976. "Differential Response to Anticipated Crowding: Psychological Effects of Social and Spatial Density."
Journal of Personality and Social Psychology 34:526-36.

Baum, Andrew and Paul B. Paulus. 1991. "Crowding." Pp. 533-70 in Handbook of Environmental Psychology, vol. 1, edited by D. Stokols and I. Altman. Malabar, FL: Krieger.

Baum, Andrew and Stuart Valins. 1977. Architecture and Social Behavior: Psychological Studies of Social Density. Hillsdale, NJ: Erlbaum.

_. 1979. "Architectural Mediation of Residential Density and Control: Crowding and the Regulation of Social Contact." Pp. 131-75 in Advances in Experimental Social Psychology, vol. 12, edited by L. Berkowitz. New York: Academic.

Booth, Alan. 1976. Urban Crowding and Its Consequences. New York: Praeger.

Booth, Alan and John Cowell. 1976. "Crowding and Family Relations." Journal of Health and Social Behavior 17:204-20.

Booth, Alan and John N. Edwards. 1976. "Crowding and Health." American Sociological Review 41:308-32.

Booth, Alan, Susan Welch, and David R. Johnson. 1976. "Crowding and Urban Crime Rates." Urban Affairs Quarterly 11:291-307.

Calhoun, John B. 1962. "Population Density and Social Pathology.” Scientific American 206:139_ 48.

Cassel, John. 1974. "Psychosocial Processes and 'Stress': Theoretical Formulation.” International Journal of Health Services 4:471-82.

Cleary, Paul D. 1987. "Gender Differences in Stress-Related Disorders." Pp. 144-56 in Gender and Stress, edited by R. C. Barnett, L. Biener, and G. K. Baruch. New York: Free Press.

Cloward, Richard C. and Frances F. Piven. 1990. "Why People Deviate in Different Ways." Pp. 71-100 in New Directions in the Study of Justice, Law, and Social Control, prepared by the School of Justice Studies, Arizona State University. New York: Plenum.

Dohrenwend, Bruce P. and Barbara S. Dohrenwend. 1976. "Sex Differences and Psychiatric Disorders." American Journal of Sociology 81:1447-54.

Dohrenwend, Bruce P., Barbara S. Dohrenwend, Madelyn S. Gould, Bruce Link, Richard Neugebauer, and Robin Wunsch-Hitzig. 1980. Mental Illness in the United States: Epidemiological Estimates. New York: Praeger.

Dooley, Braddie B. 1978. "Effects of Social Density on Men with 'Close' or 'Far' Personal Space." Journal of Population 1:251-65.

Duvall, Donna and Alan Booth. 1978. "The Housing Environment and Women's Health.” Journal of Health and Social Behavior 19:410-17.

Epstein, Yakov M. and Robert A. Karlin. 1975. "Effects of Acute Experimental Crowding." Journal of Applied Social Psychology 4:34-53.

Evans, Gary W. and Stephen J. Lepore. 1993. 
"Household Crowding and Social Support: A Quasiexperimental Analysis." Journal of Personality and Social Psychology 65:308-16.

Evans, Gary W., M. N. Palsane, Stephen J. Lepore, and Janea Martin. 1989. "Residential Density and Psychological Health: The Mediating Effects of Social Support." Journal of Personality and Social Psychology 57:994-99.

Evans, Gary W., Eunjue Rhee, Camille Forbes, Karen Mata Allen, and Stephen J. Lepore.2000. "The Meaning and Efficacy of Social Withdrawal as a Strategy for Coping with Chronic Residential Crowding." Journal of Environmental Psychology 20:335-42.

Factor, Robert and Ingrid Waldron. 1973. "Contemporary Population Densities and Human Health." Nature 243:381-84.

Freedman, Jonathan L., Alan S. Levy, Roberta Welte Buchanan, and Judy Price. 1972. "Crowding and Human Aggressiveness.” Journal of Experimental Social Psychology 8:528-48.

Gabe, Jonathan and Paul Williams. 1986. "Is Space Bad for Your Health? The Relationship between Crowding in the Home and Emotional Distress in Women." Sociology of Health and Illness 8:351-71.

Galle, Omer R. and Walter R. Gove. 1978. "Overcrowding, Isolation, and Human Behavior: Exploring the Extremes in the Population Distribution." Pp. 95-132 in Social Demography, edited by Karl E. Taeuber, Larry L. Bumpass, and James A.Sweet. New York: Academic Press.

Gillis, A. R. 1977. "High-Rise Housing and Psychological Strain.” Journal of Health and Social Behavior 18:418-31.

1979. "Household Density and Human Crowding: Unraveling a Non-Linear Relationship." Journal of Population 2:104-17.

Gove, Walter R. 1979. "Sex Differences in the Epidemiology of Mental Disorder: Evidence and Explanations." Pp. 23-68 in Gender and Disordered Behavior: Sex Differences in Psychopathology, edited by Edith S. Gomberg and Violet Franks. New York: Brunner/Mazel, Inc.

Gove, Walter R. and Michael Hughes. 1983. Overcrowding in the Household: An Analysis of Determinants and Effects. New York: Academic Press.

Gove, Walter R., Michael Hughes, and Omer R. Galle. 1979. "Overcrowding in the Home: An Empirical Investigation of its Possible Pathological Consequences." American Sociological Review 44:59-80.

Horwitz, Allan V. 2002. "Outcomes in the Sociology of Mental Health and Illness: Where Have We Been and Where are We Going?" Journal of Health and Social Behavior 43:143-51.

Horwitz, Allan V. and Lorraine Davies. 1994. "Are Emotional Distress and Alcohol Problems Differential Outcomes to Stress?: An Exploratory Test." Social Science Quarterly 75:607-21.
Horwitz, Allan V. and Helene Raskin White. 1987. "Gender Role Orientations and Styles of Pathology among Adolescents." Journal of Health and Social Behavior 28:158-70.

1991. "Becoming Married, Depression, and Alcohol Problems among Young Adults." Journal of Health and Social Behavior 32:221-37.

Horwitz, Allan V., Helene Raskin White, and Sandra Howell-White. 1996. "The Use of Multiple Outcomes in Stress Research: A Case Study of Gender Differences in Responses to Marital Dissolution." Journal of Health and Social Behavior 37:278-91.

Ineichen, Bernard and Douglas Hooper. 1974. "Wives' Mental Health and Children's Behaviour Problems in Contrasting Residential Areas.' Social Science and Medicine 8:369-74.

Karlin, Robert A., Yakov M. Epstein, and John R. Aiello. 1978. "Strategies for the Investigation of Crowding.” Pp. 71-88 in Design for Communality and Privacy, edited by Aristide H. Esser and Barrie B. Greenbie. New York: Plenum Press.

Kessler, Ronald C., Katherine A. McGonagle, Shanyang Zhao, Christopher B. Nelson, Michael Hughes, Suzanne Eshleman, Hans-Ulrich Wittchen, and Kenneth S. Kendler. 1994. "Lifetime and 12-Month Prevalence of DSM-III-R Psychiatric Disorders in the United States." Archives of General Psychiatry 51:8-19.

Lennon, Mary Clare. 1987. "Sex Differences in Distress: The Impact of Gender and Work Roles." Journal of Health and Social Behavior 28:290-305.

Lepore, Stephen J., Gary W. Evans, and Margaret L. Schneider. 1991. "Dynamic Role of Social Support in the Link between Chronic Stress and Psychological Distress." Journal of Personality and Social Psychology 61:899-909.

Loo, Chalsa M. 1972. "The Effects of Spatial Density on the Social Behavior of Children." Journal of Applied Social Psychology 2(4):372-81.

1973. "Important Issues in Researching the Effects of Crowding on Humans." Representative Research in Social Psychology 4:219-26.

1978. "Density, Crowding, and Preschool Children.” Pp. 371-86 in Human Response to Crowding, edited by A. Baum and Y. Epstein. Hillsdale, NJ: Erlbaum.

Mackintosh, Elizabeth, Susan Saegert, and Sheree West. 1975. "Two Studies of Crowding in Urban Public Spaces." Environment and Behavior 7:159-84.

Marsella, Anthony J., Manuel Escudero, and Paul Gordon. 1970. "The Effects of Dwelling Density on Mental Disorders in Filipino Men." Journal of Health and Social Behavior 11:288-94.

Milgram, Stanley. 1970. "The Experience of Living in Cities." Science 167:1461-68.

Myers, Jerome K., Myrna M. Weissman, G. L. Tischler, C. E. Holzer III, P. J. Leaf, Helen Orva- 
schel, J. Anthony, Jeffrey H. Boyd, Jack D. Burke, Morton Kramer, and R. Stolzman. 1984. "Six Month Prevalence of Psychiatric Disorders in Three Communities, 1980 to 1982." Archives of General Psychiatry 41:959-67.

Nolen-Hoeksema, Susan. 1987. "Sex Differences in Unipolar Depression: Evidence and Theory." Psychological Bulletin 101:259-82.

Pearlin, Leonard I. 1989. "The Sociological Study of Stress." Journal of Health and Social Behavior 30:241-56.

Radloff, Lenore. 1977. "The CES-D Scale: A SelfReport Depression Scale for Research in the General Population." Applied Psychological Measurement 1:385-401.

Raudenbush, Stephen W., Anthony S. Bryk, and Richard T. Congdon, Jr. 2000. HLM 5: Hierarchical Linear and Nonlinear Modeling. Lincolnwood, IL: Scientific Software International, Inc.

Regier, Darrell A., Jeffrey H. Boyd, Jack D. Burke, Jr., Donald S. Rae, Jerome K. Myers, Morton Kramer, Lee N. Robins, Linda K. George, Marvin Karno, and Ben Z. Locke. 1988. "OneMonth Prevalence of Mental Disorders in the United States." Archives of General Psychiatry 45:977-86.

Regoeczi, Wendy C. 2002. "The Impact of Density: The Importance of Nonlinearity and Selection on Flight and Fight Responses." Social Forces 81:505-30.

Robbins, Cynthia. 1989. "Sex Differences in Psychosocial Consequences of Alcohol and Drug Use." Journal of Health and Social Behavior 30:117-30.

Robins, Lee N., John E. Helzer, Myrna M. Weissman, Helen Orvaschel, Ernest Gruenberg, Jack D. Burke, Jr., and Darrell A. Regier. 1984. "Lifetime Prevalence of Specific Psychiatric Disorders in Three Sites." Archives of General Psychiatry 41:949-56.

Rodin, J., S. K. Solomon, and J. Metcalf. 1978. "Role of Control in Mediating Perceptions of Density." Journal of Personality and Social Psychology 36(9):988-99.

Rosenfield, Sarah. 1980. "Sex Differences in Depression: Do Women Always Have Higher Rates?" Journal of Health and Social Behavior 21:33-42.

. 1992. "The Costs of Sharing: Wives' Employment and Husbands' Mental Health."
Journal of Health and Social Behavior 33:213-25.

1999. "Splitting the Difference: Gender, the Self, and Mental Health." Pp. 209-22 in Handbook of the Sociology of Mental Health, edited by Carol S. Aneshensel and Jo C. Phelan. New York: Kluwer Academic/Plenum Publishers.

2000. "Gender and Dimensions of the Self: Implications for Internalizing and Externalizing Behavior." Pp. 23-36 in Gender and Its Effects on Psychopathology, edited by Ellen Frank. Washington, DC: American Psychiatric Press.

Rosenfield, Sarah, Jean Vertefuille, and Donna D. McAlpine. 2000. "Gender Stratification and Mental Health: An Exploration of Dimensions of the Self." Social Psychology Quarterly 63: 208-23.

Simmel, Georg. [1905] 1957. "The Metropolis and Mental Life." Pp. 635-46 in Cities and Society, edited by P. K. Hatt and A. J. Reiss, Jr. New York: Free Press.

Simon, Robin W. 1998. "Assessing Sex Differences in Vulnerability among Employed Parents: The Importance of Marital Status." Journal of Health and Social Behavior 39:38-54.

Stokols, Daniel. 1972. "On the Distinction between Density and Crowding: Some Implications for Future Research." Psychological Review 79:275-77.

Stokols, Daniel, Marilyn Rall, Berna Pinner, and John Schopler. 1973. "Physical, Social, and Personal Determinants of the Perception of Crowding." Environment and Behavior 5:87-115.

Sundstrom, Eric. 1978. "Crowding as a Sequential Process: Review of Research on the Effects of Population Density on Humans." Pp. 32-71 in Human Response to Crowding, edited by A. Baum and Y. M. Epstein. Hillsdale, NJ: Erlbaum.

Turner, Heather A. and R. Jay Turner. 1999. "Gender, Social Status, and Emotional Reliance." Journal of Health and Social Behavior 40:360-73.

Umberson, Debra, Kristi Williams, and Kristin Anderson. 2002. "Violent Behavior: A Measure of Emotional Upset?" Journal of Health and Social Behavior 43:189-206.

Wirth, Louis. 1938. "Urbanism as a Way of Life." American Journal of Sociology 44:1-24. 